\title{
3D DIGITALIZÁLÁS IPARI DRÓN SEGÍTSÉGÉVEL
}

\section{D DIGITALIZATION WITH INDUSTRIAL DRON}

\author{
Kun Krisztián ${ }^{1 *}$, Török Ádám Imre ${ }^{1}$ \\ ${ }^{1}$ Innovatív Járművek és Anyagok Tanszék, GAMF Műszaki és Informatikai Kar, Neumann János Egyetem, \\ Magyarország \\ https://doi.org/10.47833/2021.1.ENG.003
}

\section{Kulcsszavak: \\ 3D digitalizáció \\ Ipari drón \\ Structure from motion \\ Pontfelhő generálás \\ UAV}

\section{Keywords:}

3D digitization

Industrial drone

Structure from motion

Point cloud generation

UAV

\section{Cikktörténet:}

Beérkezett 2021. Március 4.

Átdolgozva 2021. Március 20.

Elfogadva 2021. Április 5.

\begin{abstract}
Összefoglalás
A pilóta nélküli légijármüveket kezdetben a hadiiparban alkalmazták nehezen megközelíthetö küldetések során. Napjainkban a drónok szinte az összes iparágban elöfordulnak és egyre összetettebb feladatok ellátására alkalmasak. Felhasználásukat tekintve elöfordulnak eltérő nagyságú, felépitésü és vezérlésü kivitelben. A kutatás témája egy ipari drónnal segített $3 D$ digitalizálás. A folyamat során egy geodéziai mérötornyot digitalizálunk, majd a felvételek segítségével $3 D$ modellalkotást végzünk különböző szoftverek teljesitményét összehasonlítva.

Abstract
Unmanned aerial vehicles were initially used in the military
industry for hard-to-reach missions. Today, drones are found in
almost all industries and are becoming increasingly complex in
structure. Unmanned aerial vehicles of different sizes,
constructions and types are used for special applications. The
topic of the research is $3 D$ digitization assisted by an industrial
drone. In the process, we digitize a geodetic measuring tower
and then use the images to create a $3 D$ model comparing the
performance of different software.
\end{abstract}

\section{Bevezetés}

A pilóta nélküli légijárművek (UAV - Unmanned Aerial Vehicle) lassan a mindennapi életünk szerves részét képezik, misem igazolja ezt jobban, mint az Egyesült Államok Szövetségi Légiközlekedési Hatósága (US FAA - US Federal Aviation Administration) által készített elemzés és előrejelzés, amelyet a drónok jelenlegi, valamint jövőbeli piaci igényeiröl állítottak össze. A felmérés megállapította, hogy a kereskedelmi drónok piaca a vártnál is gyorsabban növekedett, illetve egészen 2023-ig a jelenleginél háromszor nagyobbra nőhet. Ezzel szemben az ipari drónok piaca úgy tünik, hogy a közeljövőben stagnálni fog [1].

A különböző ipari területeken, valamint a lakossági szinten történő felhasználása teszi a pilóta nélküli légijárműveket igen sokoldalú eszközöké. Így a dróntechnológia és a hozzá kötődő iparágak dinamikusan és folyamatosan fejlődtek, továbbá az elkövetkezendő évtizedekben új magasságokat érhetnek el. Az elkövetkezendő évek drónpiacának alakulását az 1. ábra szemlélteti [2].

\footnotetext{
* Kapcsolattartó szerző. E-mail cím: kun.krisztian@gamf.uni-neumann.hu
} 


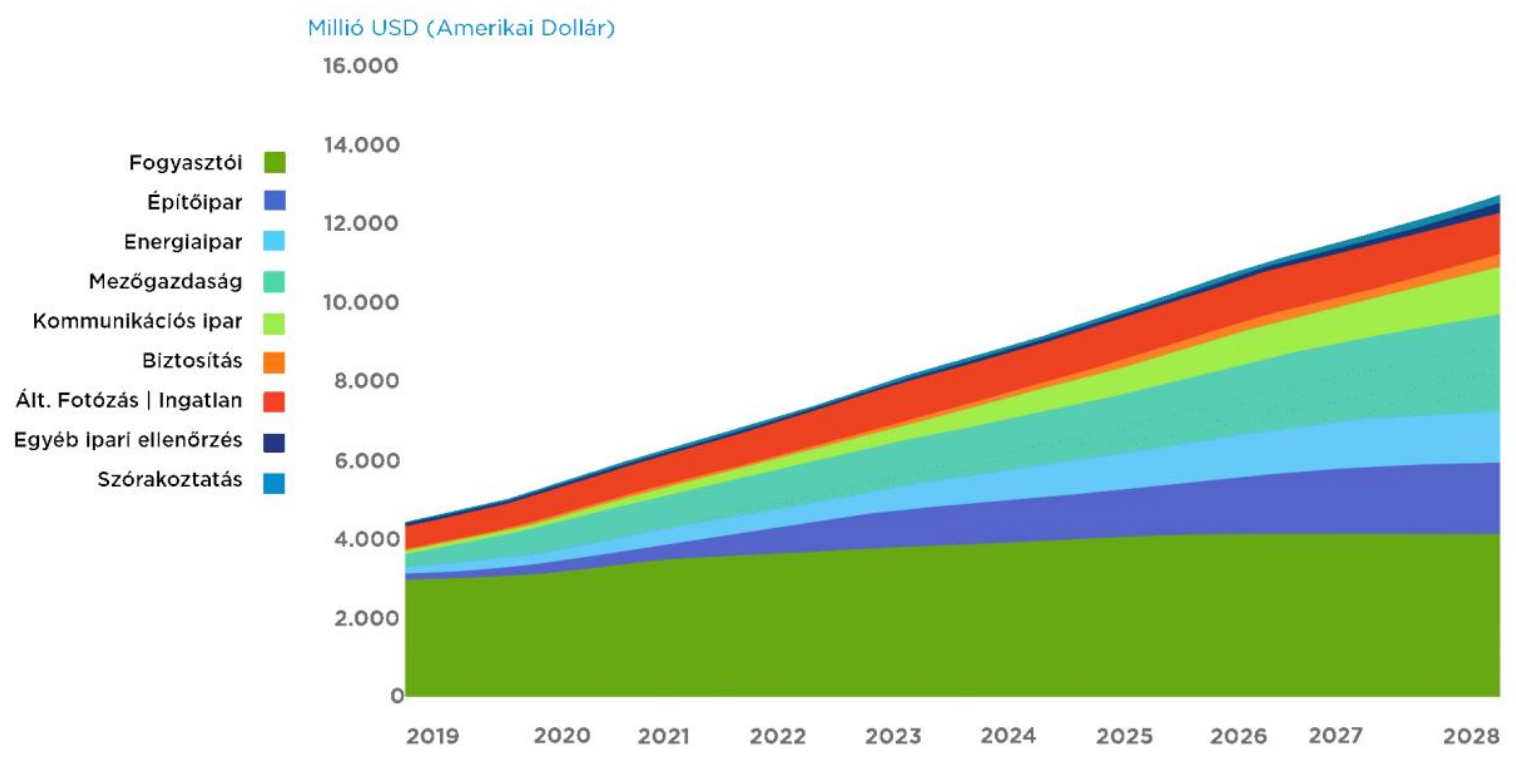

1. ábra. A drónpiac fogyasztói elörejelzése felhasználási terület szerint [2].

Az ipari drónok felhasználása igen sokrétü lehet, alkalmazhatóak a mezőgazdaságban, a közbiztonság területén, a rendészetben és az építőiparban is. A mezőgazdasági ágazatban a technológia alkalmazásási példái között szerepel a talajmintavétel, a gyomirtás, a tápanyagpótlás, a terményhozam-vizsgálat és a növényvédelem is. A közbiztonság területén veszélyes csomópontok azonosítására, vagyoni károk felmérésére, túlélők keresésére használják a drónokat. Az építőipar kiemelt felhasználója a dróntechnológiában rejlő lehetőségeknek. Nagyfelbontású felvételek rendszeresítve szolgálhatnak valós idejü adatokkal készülő projektekről, ellenőrzhetők az építési területeket. Megfelelő szoftver alkalmazásával összefüzhetnek későbbi vizsgálatra. [1] [2] [3]

A Drone mapping egy olyan megoldási forma, amelynek lényege, hogy drón által készített képeket egy célszoftver segítségével összekapcsolja egy ortofotóvá. Az ortofotó abban különbözik egy hagyományos képtöl, hogy azon rögzített méretarány mellett, geometriai torzulás nélkül, megfelelő program használatával pontos mérések végezhetők.

A fotogrammetria módszerek felhasználását a térbeliség visszaállítása alkalmazzuk. A fényképezés során a térbeli objektum 2D leképezését kapjuk. A módszer során a harmadik dimenzió visszanyerése több kép együttes használatával megy végbe. A légi fotogrammetria segítségével a földfelszín 3 dimenzióban leképezhető, illetve térképezhető. [3]

\section{Pilóta nélküli légijárművekhez alkalmazható fotogrammetriai alapok}

Mind a térfotogrammetriai eljárásokon, mind a síkfotogrammetria csoporton belül megtalálhatóak az analóg, az analitikus és a digitális alkalmazási módszerek. A légi fotogrammetria a digitális fotogrammetriára épít, amely során digitális felvételek számítástechnikai eszközökkel kerülnek kiértékelésre. A kiértékeléshez fontos, hogy olyan számítógépet alkalmazzanak, amely képes több nagymennyiségű adatból álló felvételek kezelésére, tárolására, illetve rendelkezzen a lépéseket automatizáló programmal. A kiértékelés eredménye a legtöbb esetben terepi koordináta pontok digitális formátumban. Az értékek pontossága nagymértékben függ az elkészített digitális képek felbontásától, ám a számítástechnika fejlődése és a nagyfelbontású kamerák megjelenése miatt ez egyre jobban kiküszöbölhető. A módszer lényege, hogy a tárgy alakját egymást követő, átfedő és különböző kamera pozíciókból készült képsorozatok segítségével állítja vissza [11].

Abban az esetben, amikor az objektum információit egyetlen kép használatával szolgálja, akkor egyképes (single image) fotogrammetriáról beszélünk. A sztereo fotogrammetria abban tér el ettől, hogy ugyanaz a jelenet két, eltérő kamera pozícióból kerül megörökítésre. A 3D-s koordináták eléréséhez szükséges pontokat a kollinearitási egyenletek határozzák meg.

A légi fotogrammetria alapvető technikájának számít, amely során a képek kétféleképpen rögzíthetőek. Egyik szerint a kamerákat egymástól elöre meghatározott távolságra helyezik el, a másik esetben két külön lencsével rendelkező gépet kell használni. 


\subsection{Structure from Motion technika}

A digitális fotogrammetriai technikák közé tartozik, a sztereo fotogrammetria elméletére épülö Structure from Motion (SfM) algoritmus, amely a képek közötti parallaxisokat ${ }^{*}$ használja a 3D modellek létrehozásához. Az SfM technikát már a 2000-es évek óta alkalmazzák különféle célokra, például robotika vagy az automatikus alakfelismerő algoritmusok terén. Ahelyett, hogy minden felvételnél különböző kamerát alkalmaznánk az SfM egyetlen mozgó kamerát használ. [6][7]

\section{A folyamat három fő lépésböl tevődik össze:}

- A képsorozat jellemzőinek azonosítása, összehangolása, valamint a 3D geometria becslése. (A kamera pozíció és orientáció segítségével.)

- Az elhelyezett földi koordináta (referencia) pontok (Ground Control Point - GCP) felhasználása pontfelhő optimalizáláshoz. - Ez a lépés nem feltétele a digitalizációnak, de az eredmények minőségén és a feldolgozás sebességén jelentősen segít. [9]

- MVS képalkotó módszer (Multi-View Stereo) használata egy sűrü pontfelhő létrehozásához. [4]

A 3D pontok a mért képpozíciókból két vagy több nézetben készült felvételek alapján kiszámíthatóak, ez a háromszögelés. Ideális esetben a 3D pontok a térben a 2D fotókra vetített sugarak metszéspontjába esnek, azonban a felvételek készítése közben felléphetnek hatások, amelyek alacsony minőségü, torzított képeket eredményeznek. Ezeket ki kell szürni a végleges, feldolgozásra kerülö felvételek közül. A Structure from Motion technika adatgyűjtési folyamatát és a háromszögelést szemlélteti a 2. ábra.

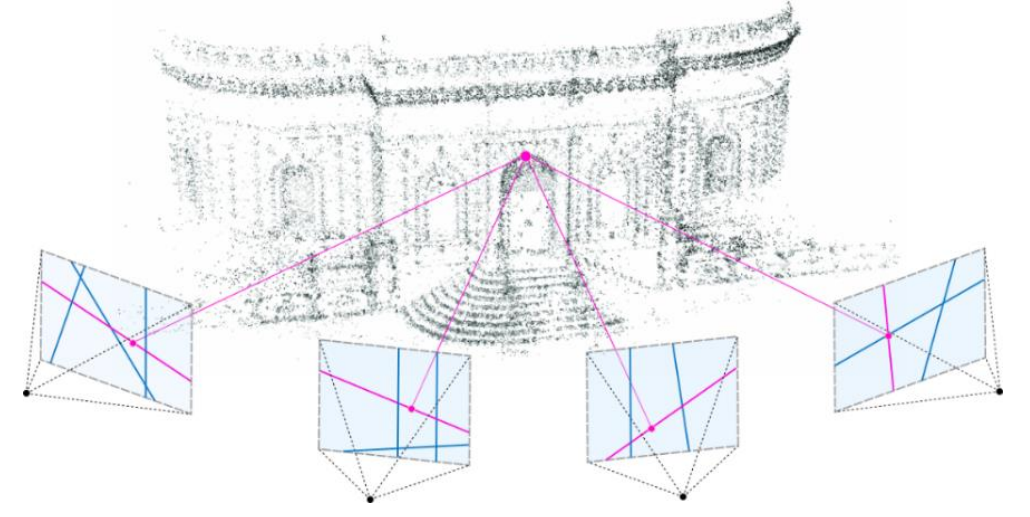

2. ábra. A Structure from Motion technika adatgyüjtési folyamata [10]

\subsection{A kutatáshoz alkalmazott berendezések}

A többforgószárnyas, függőlegesen felszállni képes (Vertical Take Off and Landing - VTOL) drónok segítségével lehetőség nyílik épületek vizsgálatára, elemzésére és 3D modellek alkotására. A Tarek Rakha és Alice Gorodetsky által írt tanulmány összefoglalja a jelenleg alkalmazott hőképalkotó eljárásokat repülő eszközök segítségével, valamint egy drónnal segített, épület felmérési módszert mutat be. Kutatásukban az építményről készült képeket egy DJI Inspire drón tárolta el. Az általuk végzett vizsgálatban a képekböl Pix4D, Agisoft Metashape és DroneDeploy programokban 3D-s pontfelhőt generáltak, majd a végeredményböl állapították meg a szoftverek pontosságát és megbízhatóságát. [4] [5]

A kutatásunk területe hasonló, azonban a megvalósítás különböző: más drónnal és más szoftver használatával végeztük el a kísérletet. A RealityCapture egy 2016-ban kiadott feldolgozószoftver, amelyet az említett publikációban is szereplő Agisoft Metashape programmal vetettünk össze [5]. A digitalizációhoz szükséges képek elkészítését a Neumann János Egyetem tulajdonában lévő ipari drónnal végeztük. Az alkalmazott drón egy DJI Spreading Wings S900 típusú modell, amelyet a feladat elvégzéséhez egy digitális kamerával és kamera stabilizátorral (Gimbal) kellett ellátni.

\footnotetext{
*Parallaxis: A testek egymáshoz viszonyított helyzetének változása eltérő irányokból nézve.
} 


\section{A rendelkezésre álló felszerelések a következök voltak:}

- DJI Spreading Wings S900 ipari drón

- Zenmuse H4-3D kamera stabilizátor (gimbal)

- GoPro Hero 4 kamera

- Spektrum DX18 távírányító

Az installált akciókamera a távirányítón található monitorral áll összeköttetésben, a monitoron több adatot is megjelenít a drónnal kapcsolatban a kamera valós időben vett képén kívül. Ezek között szerepel a drón akkumulátorában lévő aktuális feszültség, a látható müholdak száma, a felszállástól mért magasság, valamint a drón aktuális üzemmódjának a jelzése. A repülési művelethez módosításokra volt szükség, ugyanis a rajta lévő GoPro kamerával nem volt lehetséges fotók, csak videók rögzítése. Mivel a képrögzítési funkciót nem lehetett a távirányítóra programozni, ezért egy kétkamerás rendszer kiépítése mellett döntöttünk.

\section{Az utólagosan beépített egységek:}

- Egyedi kameratartó konzol

- STORM32 BGC kamera stabilizátor (gimbal)

- SJCAM SJ8 Pro sportkamera (távvezérlővel)

Az SJCAM SJ8 Pro akciókamerával készültek a kutatáshoz nélkülözhetetlen felvételek, mivel jóval nagyobb, 12 megapixel felbontású képek készítésére alkalmas. A képek készítése egy vezeték nélküli kapcsolatot kialakító, gyári kiegészítővel történt.

\section{A digitalizációs folyamat}

Az összeszerelést követően elvégeztünk egy tesztrepülést a drónnal, annak érdekében, hogy megfigyelhessük a repülés közben fellépő pozíciótartás befolyásolják-e a képalkotás stabilitását. $A$ kamera stabilitásának ellenőrzése után kiválasztottuk a digitalizálásra szánt építményt, amely egy geodéziai mérőtorony lett. Megközelíthetősége és magassága miatt vált szükségessé drón alkalmazása. A geodéziai mérőtornyok olyan földmérési célokat szolgáló építmények, amelyek a 70es években épültek Mivel messziröl is irányozhatóak, létfontosságúak voltak hosszúoldalú sokszögelés kivitelezésében. A digitalizált torony Kadafalva határában, 1981-ben épült, magassága 30 méter. Az objektum megválasztása után kiválasztottuk a repülési útvonalat (3. ábra). A szakirodalmak szerint a szkennelt szánt tárgy vagy terület geometriájától függően alkalmazható vízszintes-, függöleges pásztázás, valamint spirál- vagy kör mentén történő pályakövetés. A müvelet során, annak érdekében, hogy a tárgy minden részletét rögzítsük körpályát repültünk, amit két távolságban is elvégeztük. Egy körpályát 16 szakaszra bontottunk. Mivel manuális irányítással nehezen repülhető végig a pontos pálya, jobb eredmény érdekében érdemes pályagenerálásra alkalmas szoftvert használni. A DJI S900 típushoz azonban nem áll rendelkezésre ilyen szoftver.

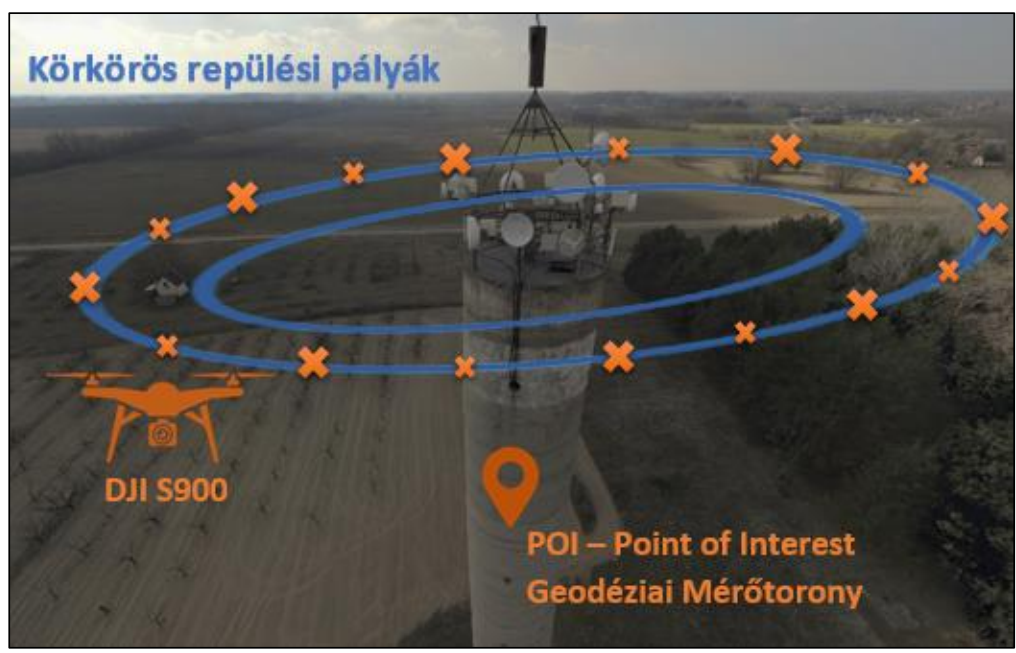

3. ábra. A geodéziai mérötorony körül meghatározott körkörös repülési terv. 
A 3D digitalizáláshoz készített felvételeket importáltuk a képfeldolgozó programba, amelyben a képek szükséges rendezése és ellenőrzése után generálható egy un. ritka pontfelhő, annak érdekében, hogy az objektum behatárolhatóvá válhasson. A generálandó terület leszükítésével a sürü pontfelhő előállítási ideje nagymértékben csökkenthető. Az alkalmazott programokban létrehozott ritka pontfelhök összehasonlítását szemlélteti a 4. ábra.

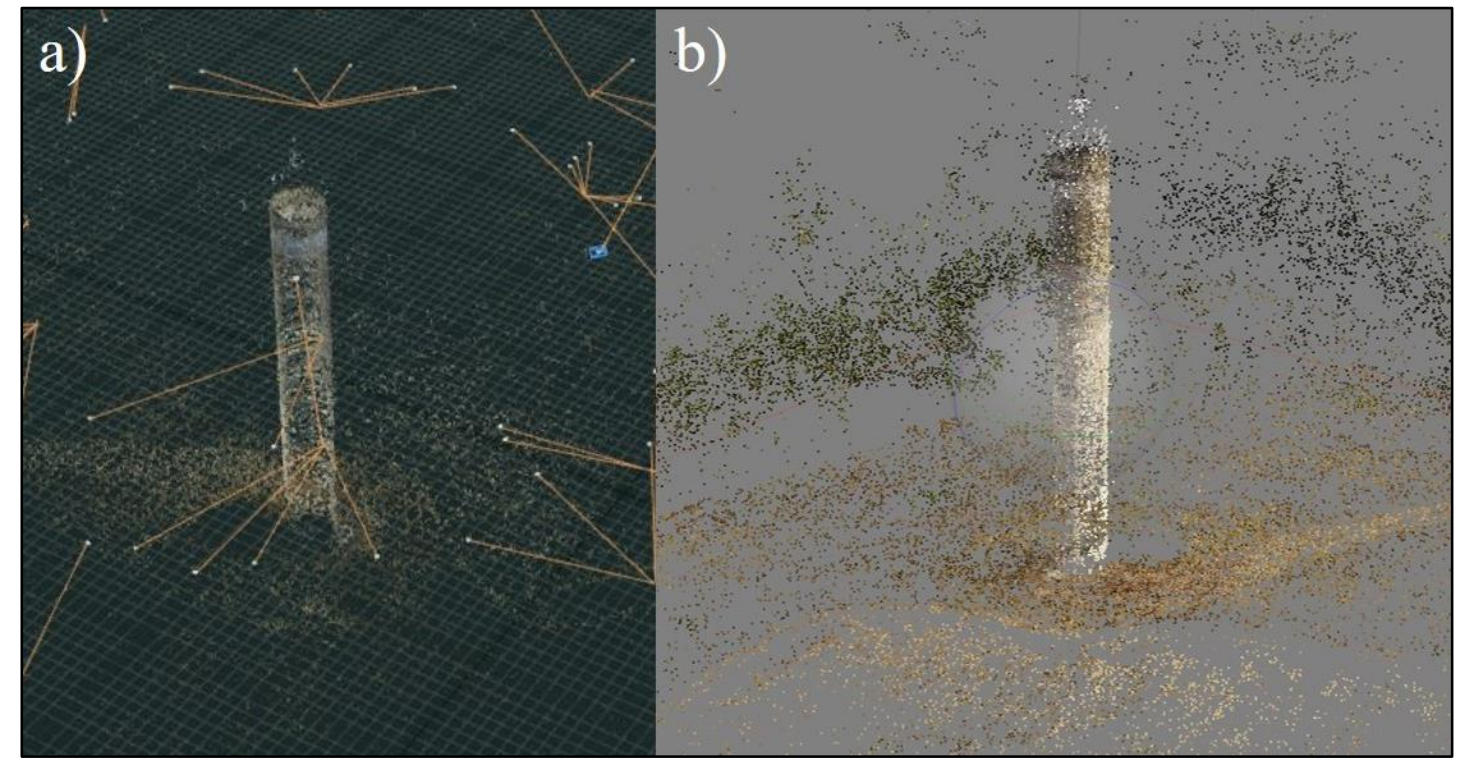

4. ábra. Ritka pontfelhö modellek: RealityCapture (a) és Agisoft Metashape (b)

Az ábrákon is látható, hogy a modellalkotás nem teljes, mivel a ritka pontfelhő fázisánál csak egyes pontokat jelenítenek meg a szoftverek. A ritka pontfelhő a közös kulcspontokat rögzíti, de a képek összeillesztése csak a végleges modellnél valósul meg.

A következő lépés a pontfelhők sürítése, amely a végleges testet alkotja. Megfigyelhető, hogy az épület henger alakú törzse jól kivehetően, részletesen rekonstruált, azonban a tetején elhelyezkedő antenna-rendszer már kevésbé. Ennek az oka, hogy nem készült elegendő számú és közelségü felvétel az említett részletről. A szoftverek által generált eredményeket az 5 . ábra szemlélteti.

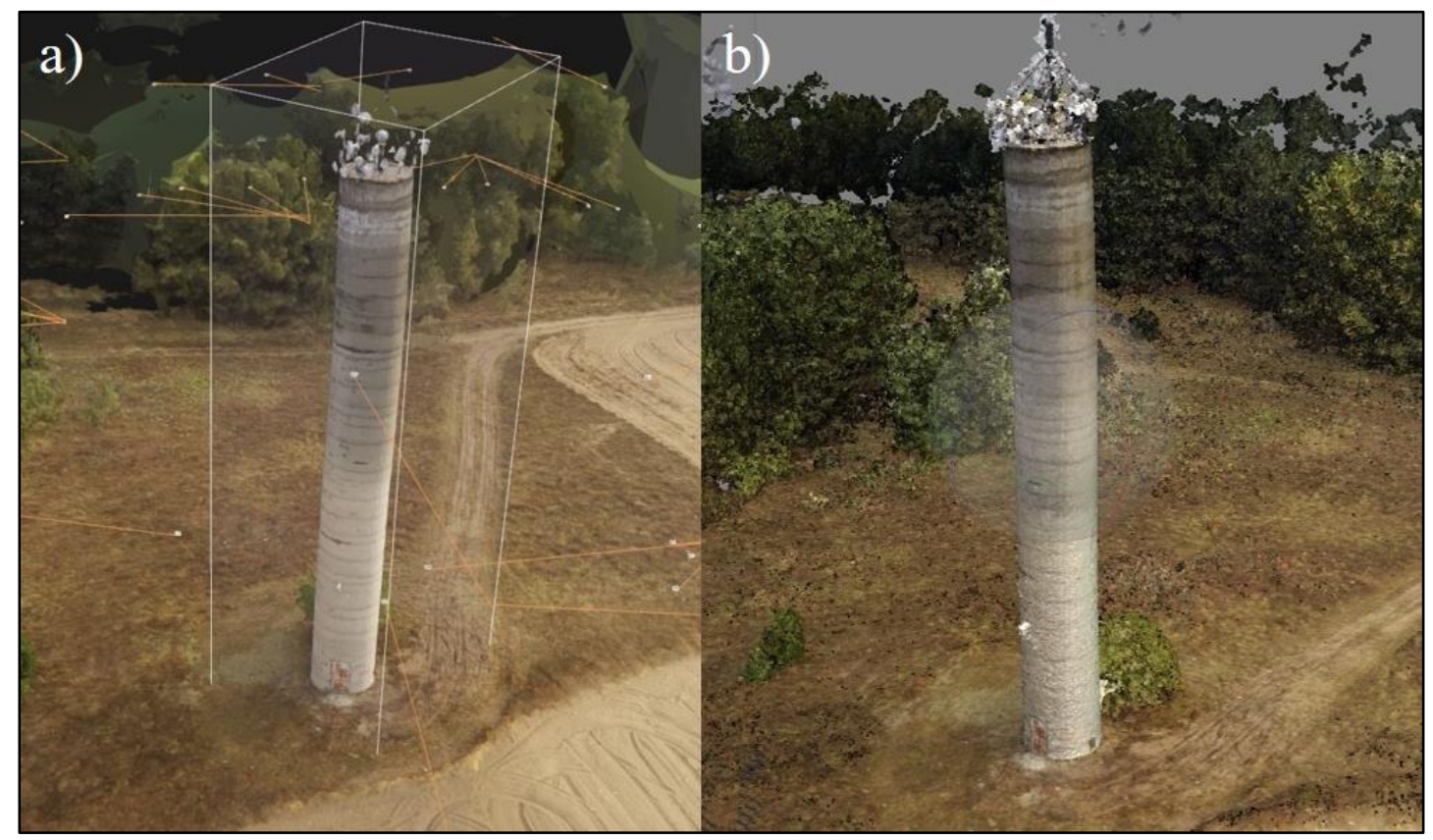

5. ábra. A pontfelhő sürítés eredményei: RealityCapture (a) és Agisoft Metashape (b) 
A kapott digitális modellek alapján megállapíthatóak a különbségek a szoftverek pontfelhő megjelenítésének módjában.

A RealityCapture nagy elönye, hogy a képek közös kulcspontjainak keresésénél a határozatlan tartományokat kitölti a szomszédos textúra elemeket felhasználva. Ezt úgy oldja meg, hogy a pontfelhőn több zajszürési algoritmust futtat, majd a megfelelő analízis után egy poligonhálót generál. A poligonháló létrehozása úgy történik, hogy a szoftver a 3D-s térben rögzített pontokat (amelyeket vertexnek hívunk) szakaszokkal köti össze, háromszögelt modellt alkotva. Ennek eredményeképp egy zárt felületmodelt kapunk, amely nem rendelkezik felületfolytonossági hibákkal. Megfigyelhető, hogy a szoftver algoritmusa rendkívül jó pontszüréssel rendelkezik, így a torony lábazatán 2 méter magasságban látható falfestékek is kivehetőek.

Az Agisoft Metashape program minden olyan pontot, amelyet érzékel, azt megjeleníti a pontfelhőben, azonban ez szemmel láthatóan gyengébb digitalizációt eredményez. Az Agisoft szoftverben a poligonháló generálása nem eredményez zárt felületmodellt. Valószínüsíthetően a pontszürés kevésbé összetett, ezért azokon a területeken, amelyeknél a szoftver számára nem rögzítenek kellö információt (pont koordinátákat) a képek üres területek láthatóak. Az algoritmus azokat a kulcspontokat, amelyek alapján további, folyotonos poligon-felület generálása nem lehetséges kevésbé szüri ki, ezért hathat a modell szemcsésnek.

A szoftverekben létrehozott, digitalizált modellek egy kiemelt részletét mutatja a 6 . ábra.

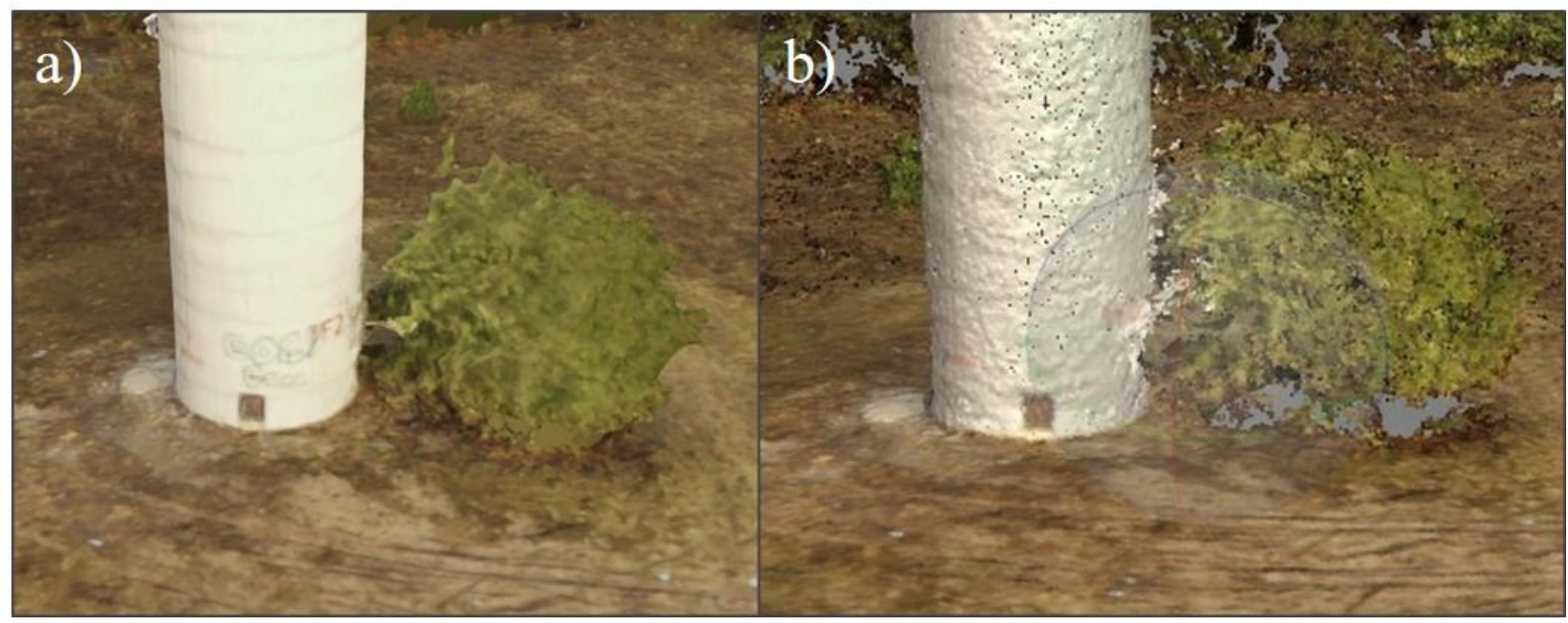

6. ábra. A szoftverek közötti feldolgozási minőség eltérése: RealityCapture (a), Agisoft Metashape (b)

\section{4. Összegzés}

A programok tesztelése után világosabb képet kaptunk a technológiában rejlő lehetőségekről. A kutatás alapjául szolgál az eredményekre alapuló 3D digitalizációkhoz, valamint tapasztalatszerzést jelentett a drónnal végezhető fotometriai feladatok végzéséhez is. Az alkalmazott szoftvereknél megfigyelhető az SfM technikával végzett digitalizáció fejlődése, ugyanis a vizsgált RealityCapture és az Agisoft Metashape fejlesztése között 6 év telt el.

A kutatásban olvasható módszer egyik legnagyobb előnye az építési területeken való alkalmazása, ahol csökkentheti a baleseti kockázatokat abban az esetben, ha egy nehezen elérhető helyet drónnal térképeznek fel [1]. Továbbá a modellalkotás tárgyalt módszere nagyobb épületek rekonstrukciójában is jól használható.

Napjainkban az építőiparban kiemelt figyelmet kap, az úgynevezett Building Information Modeling* (BIM) módszertan. A módszer az épületek tervezési és építési folyamatát szimulációs és optimalizációs folyamattal segíti digitális modelleket felhasználva. A BIM tehát magában foglalja az építési folyamathoz köthető szabványok, folyamatok és technológiák szerves részét, azonban alapjait a 3D modellalkotás adja, amelyre a kutatásban bemutatott módszer jól alkalmazható.

\footnotetext{
* Building Information Modeling (BIM): digitális épületmodell-alapú tervezési módszertan
} 


\section{Irodalomjegyzék}

[1] Jelentés a drónpiaci válaszok elemzéséről és előrejelzéséről [Online] Available: https://www.dupliglobal.com/home/dronpiaci-elorejelzes (Seen: 28-Sept-2020)

[2] A dróntechnológia múltja és jelene, jövője [Online] Available: https://www.dronexpert.hu/drontechnologia-2020.html (Seen: 28-Sept-2020)

[3] Molnár Bence Attila: Modellezés mélységképek és nem metrikus felvételek alapján. Budapest, 2013. PhD Tézis [Online] Available: https://repozitorium.omikk.bme.hu/bitstream/handle/10890/5585/ertekezes.pdf (Seen: 10-Dec-2020)

[4] Ali Hosseininaveh: Photogrammetric Multi-View Stereo and Imaging Network Design. 2015. PhD Tézis [Online] Available: https://www.researchgate.net/publication/272509454 Photogrammetric MultiView Stereo and Imaging Network Design (Seen: 15-Dec-2020)

[5] Tarek Rakha; Alice Gorodetsky "Review of Unmanned Aerial System (UAS) applications in the built environment: Towards automated building inspection procedures using drones”, Pages 252-262 (2018) DOI: 10.1016/j.autcon.2018.05.002 (Seen: 5-Oct-2020)

[6] S. Avidan; A. Shashua: Trajectory triangulation: 3D reconstruction of moving points from a monocular image sequence IEEE TRANSACTIONS ON PATTERN ANALYSIS AND MACHINE INTELLIGENCE, VOL. 22, NO. 4, (April, 2000) DOI: $10.1109 / 34.845377$ (Seen: 2-Nov-2020)

[7] Benjamin, A., O’Brien, D., Barnes, G., Wilkinson, B., Volkmann, W. "Assessment of Structure from Motion (SfM) processing parameters on processing time, spatial accuracy, and geometric quality of unmanned aerial system derived mapping products." Journal of Unmanned Aerial Systems (2017) [Online] Available: https://www.uasjournal.org/sites/default/files/articles/UASJournal-Vol3-Issue1-benjamin-obrien-barnes-wilkinsonvolkmann.pdf (Seen: 5-Oct-2020)

[8] Jakob, Iglhaut., Carlos, C., Stefano P., Livia P., J, O’Connor., Jacqueline R., "Structure from Motion Photogrammetry in Forestry: a Review" Current Forestry Reports volume 5, Pages 155-168 (2019) DOI: 10.1007/s40725-019-00094-3 (Seen: 2-Nov-2020)

[9] Zimmerman, Taylor., Jansen, Karine., Miller, Jon. 2020. "Analysis of UAS Flight Altitude and Ground Control Point Parameters on DEM Accuracy along a Complex, Developed Coastline" Remote Sens. 12, no. 14: 2305. (July 2020) DOI: $10.3390 /$ rs12142305 (Seen: 10-Oct-2020)

[10] M, Geppert., V, Larsson., P, Speciale., J, L, Schönberger., M, Pollefeys. "Privacy Preserving Structure-from-Motion" European Conference on Computer Vision (ECCV) (2020) [Online] Available: https://www.microsoft.com/en-us/research/uploads/prod/2020/08/Geppert2020ECCV-1.pdf (Seen: 2-Nov-2020) 